\title{
Costs and concerns in cancer care
}

\section{Ian Haines}

Associate professor

Alfred Medical Research

and Education Precinct

Department of Medicine

Monash University at

Cabrini Hospital

Medical oncologist

Melbourne Oncology Group

Cabrini Haematology and

Oncology Centre

Melbourne

\section{Keywords \\ cost of drugs, \\ Pharmaceutical Benefits \\ Scheme}

Aust Prescr 2016;39:146-7

http://dx.doi.org/10.18773/

austprescr.2016.056
Some recently developed anticancer drugs appear to be a major advance. In metastatic malignant melanoma a number of new immune checkpoint inhibitors have created excitement and hope in a disease for which there was previously no effective treatment.' One magazine hailed them as 'the most revolutionary cancer treatment in decades'. ${ }^{2}$ These targeted drugs are likely to have a major impact on the treatment outcomes for other advanced incurable cancers too, but they are very expensive.

In practice, many of the earlier targeted cancer drugs have turned out to be disappointing. They are only suitable for a limited number of patients, and only add, on average, a few months of survival. ${ }^{3}$

The clinical trials of new anticancer drugs use highly selected patients and the reported outcomes do not relate to the general community that we treat daily. ${ }^{4}$ For the benefits these drugs deliver, the costs seem excessive. ${ }^{5,6}$ How are we to determine which new drugs are cost-effective and how do we pay for the ones that are?

Among patients with incurable metastatic melanoma 40-60\% have BRAF V600 mutations and can be treated indefinitely with oral dabrafenib plus trametinib. The cost to the Pharmaceutical Benefits Scheme (PBS) is $\$ 8759$ per drug per month ( $\$ 17518$ per month total). Patients can then be started on an immune checkpoint inhibitor, such as pembrolizumab indefinitely at $2 \mathrm{mg} / \mathrm{kg}$ every three weeks, at a cost to the PBS of $\$ 8000$ or more every three weeks, or $\$ 136000$ per year. These treatments may continue for years. Then patients can be given the cytotoxic immune modulator ipilimumab for a cost of $\$ 130000$ per course of four injections, which can be repeated if appropriate. These drugs can cost more than $\$ 500000$ per patient. None of these treatments are curative and on average they only prolong progression-free survival or overall survival by months, although some patients who would otherwise have died can have enduring benefit for years. There is no predictive biomarker for benefit from pembrolizumab or ipilimumab.

Looking at cancer therapies approved by the US Food and Drug Administration (FDA) for solid tumours between 2002 and 2012, the prolongation in median overall survival was only 2.16 months. ${ }^{7}$ Of the 12 anticancer drugs approved by the FDA in 2012 alone, only three prolonged survival, two of them by less than two months. Yet nine were priced at more than \$US10 000 per month. ${ }^{8}$
In metastatic colon cancer, the vascular endothelial growth factor (VEGF) inhibitor bevacizumab is used in many protocols. In Australia it costs up to $\$ 8000$ per month and can be used indefinitely, but only increases average survival by 0.9 months.

In 2015 a group of experts from the European Society for Medical Oncology said that many modern cancer drugs were of very little benefit to patients. They published a scoring system, unconnected with cost, that showed many drugs did not extend or improve people's lives for very long. ${ }^{9}$

To address the cost of anticancer drugs there is a role for individual patients, organisations and physicians to advocate for greater access to, and fairer prices for, effective new therapies. The doctrine of justum pretium, or just price, refers to the 'fair value' of commodities. In deciding the relationship between price and worth (or value), the doctrine advocates that, by moral necessity, price must reflect worth. This differs from the function of free-market economies where prices reflect 'what the market bears', or what buyers are willing to pay.

Some European countries are achieving comparable or superior outcomes with less outlay by considering best practice and assessing costeffectiveness. ${ }^{10-12}$ Many governments like Australia's are already using health-technology measurements for resource allocation. These often use costeffectiveness thresholds like the National Institute for Health and Care Excellence in the UK which uses $£ 20$ 000-30 000 per quality-adjusted year of life saved. Treatments exceeding this threshold are unlikely to be funded.

In the UK, setting thresholds has led to challenges from cancer groups. The subsequent publicity, threatened legal action and political pressure meant that major decisions not to fund two new targeted cancer drugs, trastuzumab and imatinib, were reversed. Consequently, the UK Government set up the Cancer Drugs Fund in 2010 and extended it to March 2016. ${ }^{10,13}$ Despite a lifetime budget of $£ 1.27$ billion, it overspent its budget for 2014-15 alone by $35 \%$. It was announced in 2016 that funding will continue but will be capped at $£ 340$ million annually. The Canadian province of Ontario developed the publicly funded Ontario Public Drug Programs in 1995. ${ }^{14,15}$ However, a growing number of high profile cases of media and political pressure have also influenced drug approvals in the province. ${ }^{10}$ 
If we are going to consider similar government programs to maintain equitable access to expensive new cancer drugs in Australia, all physicians and scientists should insist on greater transparency of the data concerning these new drugs. As the immediate past Chair of the Pharmaceutical Benefits Advisory Committee Dr Suzanne Hill says, it no longer seems appropriate for all the data supporting government funding of these very expensive drugs to remain commercial-in-confidence. She also says it is not appropriate to not collect publicly accessible de-identified data on outcomes for all patients who receive these drugs. ${ }^{16}$

Finally, we will need public debate about such targeted funding, about reducing unnecessary health expenditure elsewhere and about possibly increasing taxation. $<$

Conflict of interest: none declared

\section{REFERENCES}

1. Atkinson V. Medical management of malignant melanoma. Aust Prescr 2015;38:74-8. http://dx.doi.org/10.18773/ austprescr.2015.028

2. Chisholm D. The first real hope. A new group of drugs that target the immune system is being hailed as the most revolutionary cancer treatment in decades. New Zealand Listener 2015 Jul 2; 3921. www.listener.co.nz/current-affairs/ health-current-affairs/the-first-real-hope [cited 2016 Sep 1]

3. Ward RL. A decade of promises in personalised cancer medicine: is the honeymoon over? Med J Aust 2014;200:132-3. http://dx.doi.org/10.5694/mja14.00018

4. Heng DY, Choueiri TK, Rini BI, Lee J, Yuasa T, Pal SK, et al. Outcomes of patients with metastatic renal cell carcinoma that do not meet eligibility criteria for clinical trials. Ann Oncol 2014;25:149-54. http://dx.doi.org/10.1093/ annonc/mdt492

5. Currow DC, Aranda S. Cancer control is not beyond us ... but could be if we don't invest wisely. Med J Aust 2015;202:63. http://dx.doi.org/10.5694/mja14.01701

6. Experts in Chronic Myeloid Leukemia. The price of drugs for chronic myeloid leukemia (CML) is a reflection of the unsustainable prices of cancer drugs: from the perspective of a large group of CML experts. Blood 2013;121:4439-42. http://dx.doi.org/10.1182/blood-2013-03-490003

7. Fojo AT, Noonan A. Why RECIST works and why it should stay--counterpoint. Cancer Res 2012;72:5151-7. http://dx.doi.org/10.1158/0008-5472.CAN-12-0733

8. Kantarjian HM, Fojo T, Mathisen M, Zwelling LA. Cancer drugs in the United States: Justum Pretium--the just price. J Clin Oncol 2013;31:3600-4. http://dx.doi.org/10.1200/ JCO.2013.49.1845

9. Cherny NI, Sullivan R, Dafni U, Kerst JM, Sobrero A, Zielinski C, et al. A standardised, generic, validated approach to stratify the magnitude of clinical benefit that can be anticipated from anti-cancer therapies: the European Society for Medical Oncology Magnitude of Clinical Benefit Scale (ESMO-MCBS). Ann Oncol 2015:26:1547-73. http://dx.doi.org/10.1093/annonc/mdv249
10. Aggarwal A, Ginsburg O, Fojo T. Cancer economics, policy and politics: what informs the debate? Perspectives from the EU, Canada and US. J Cancer Policy 2014;2:1-11. http://dx.doi.org/10.1016/j.jcpo.2014.02.002

11. Drummond MF, Mason AR. European perspective on the costs and cost-effectiveness of cancer therapies. J Clin Oncol 2007;25:191-5. http://dx.doi.org/10.1200/ JCO.2006.07.8956

12. Lim CS, Lee YG, Koh Y, Heo DS. International comparison of the factors influencing reimbursement of targeted anti-cancer drugs. BMC Health Serv Res 2014;14:595. http://dx.doi.org/10.1186/s12913-014-0595-0

13. Parliament UK; Public Accounts Committee. Cancer Drugs Fund inquiry. 2016 Feb 5. www.parliament.uk/business/ committees/committees-a-z/commons-select/publicaccounts-committee/inquiries/parliament-2015/cancerdrugs-fund-15-16 [cited 2016 Sep 1]

14. Ramjeesingh R, Meyer RM, Brouwers M, Chen BE, Booth CM. Alignment of practice guidelines with targeted-therapy drug funding policies in Ontario. Curr Oncol 2013;20:e21-33. http://dx.doi.org/10.3747/co.20.1166

15. New drug funding program (NDFP) and evidence building program (EBP): approved drugs and eligibility criteria. Toronto: Cancer Care Ontario; 2016 Mar 30. www.cancercare.on.ca/toolbox/drugs/ndfp [cited 2016 Sep 1]

16. Carlisle W, Masters D. Buying time. ABC Four Corners Updated 2013 Aug 28. http://www.abc.net.au/4corners/ stories/2013/08/26/3831617.htm [cited 2016 Sep 1]

\section{FURTHER READING}

Swan N, Balendra J. Wasted. ABC Four Corners. Updated

2015 Sep 29. www.abc.net.au/4corners/stories/2015/09/28/

4318883.htm [cited 2016 Sep 1] 